\title{
Pentagon stakes claim on shuttle
}

Military space

use forecast by

\section{new directive}

\section{Washington}

The growing unease over the military's role in the US space programme was hardly calmed last week by a new presidential directive on space policy. Although the directive does not actually establish any new programmes, and consists for the most part of vague generalities, it is the most overt and explicit statement of US military space objectives ever issued by a president, and appears to reverse a long tradition of playing down the military side of American space endeavours.

And while officials of the National Aeronautics and Space Administration (NASA) are taking encouragement from the presidential fanfare that accompanied the directive - including a speech at the 4th of July shuttle landing in which President Reagan extolled the benefits that the space programme has reaped for American jobs, technology and spirit - they clearly would have been much happier had the President offered a firm commitment to future projects in the civilian space programme. NASA had in particular hoped for a goahead on a fifth shuttle orbiter and what it hopes will be its next big project, an orbiting space station.

The secret military payload on the recent shuttle flight (which is generally known to have contained the Air Force's CIRRIS infrared sensor, being developed to spot missile launches) was a visible reminder of what all the concern was about. Critics say that the shuttle, with its dual role, has effectively erased the line between civilian and military space missions. And they see NASA's acceptance of a substantial Department of Defense (DoD) role, first in the design specifications and now in the operations of the shuttle, as having been a Faustian bargain: NASA received support for a big engineering project of the sort it thrives on, but is now having to pay the price of sacrificing its civilian role more and more to military interests.

These worries have reached even strong supporters of military space projects. Senator Harrison Schmitt (Republican, New Mexico), a former astronaut, is for example seeking to redress the balance between civilian and military space programmes. The Senate's Commerce, Science and Transportation Committee earlier this year approved his proposal to make DoD increase its contributions to the shuttle by $\$ 409$ million. Schmitt says this is nothing more than a requirement that DoD should pay for use of the shuttle at the same

rate as all other users. Under Schmitt's plan, NASA would use this extra money to build a fifth shuttle and to increase its research programmes in space science and aeronautics.

The President's science adviser, Dr George Keyworth, argues that this concern is misplaced. In a briefing for reporters on the new space policy, he pointed out that the military goals set out in the directive most notably the "development of an antisatellite capability ... to deny any adversary the use of spaced-based systems that provide support to hostile military forces" - are nothing new. But he was unwilling to shed any light on why the military space programme was being made so explicit for the first time, or why an inter-agency committee set up to implement space policy under the directive will be headed by the White House's National Security Advisor.

While Keyworth spoke of the Administration's commitment to NASA's scientific mission and its general willingness to maintain NASA's current level of funding, he offered little encouragement for supporters of another big civilian project for NASA. He said a reference in the President's 4th of July speech to "establishing a more permanent presence in space" was definitely not a go-ahead for NASA's space station plans. Although "nothing is excluded", he said, "I have not yet seen comprehensive, well thought out plans for what it [a space station] will do."

Keyworth also took issue with Schmitt's plan to raise DoD contributions. NASA's budget, he said, took into account the military missions that NASA will launch; if

\section{Severe cuts unsettle Belgian universities}

\section{Brussels}

Belgium's universities are still reeling from the unexpected severity of the cuts in public subsides announced by the government last month. One thousand million Belgian francs ( $£ 11.7$ million) are to be pared from the resources of the already struggling universities.

The centre-right government hopes to save $\mathrm{BF} 8,000$ million in the whole education budget as one of many measures intended to reduce its considerable budget deficit. Savings of BF500 million will be achieved by reducing by 25 per cent the subsidies per student and by widespread salary cuts. The universities are expected to pay for teaching, administration and research out of the allocations per student even though they have already made economies.

But the government wants more hightechnology research to be carried out for which reason the research and teaching functions in the universities may have to be separated; a move has already been made in this direction with the allocation of the first
NASA receives an additional $\$ 409$ million from the military, then its budget should be cut by an equal amount.

Development of military hardware remains solely in the hands of the military. The new policy does not change that; nor does it affect the substance of those projects, beyond guaranteeing the Administration's commitment to them.

According to defence analysts, Air Force publications and published budget data, these projects range from surveillance efforts - such as the CIRRIS infrared telescope tested on the recent shuttle flight - and other "passive" missions such as navigation and communications to "active" anti-satellite capabilities. Antisatellite work makes up the bulk of research and development in the military space programme; emphasis now is on the development and testing within the next few years of an anti-satellite "miniature homing vehicle" designed to be launched from an F-15 fighter. This weapon disables a satellite simply by ramming it. According to defence analysts, it is not likely to be able to reach targets above $1,000 \mathrm{~km}$.

Basic research and development on lasers and particle beams, with the ultimate aim of producing a more sophisticated anti-satellite weapon and possibly a spacebased anti-ballistic missile system, is also receiving a lot of attention.

Another major project is the NAVSTAR “Global Positioning System", a package of 18 satellites that will allow a person on the ground equipped with a receiver to determine his position. Receivers could also be installed in missiles.

NASA's involvement in any of these

tranche of BF500 million for a programme of industrial research and development. It is hoped that the programme will help to win more public supply contracts in such fields as aeronautics, information technology and telecommunications. Hitherto, most of these contracts were given to research centres or companies.

Meanwhile, some Belgian universities are trying to make money from their own research. The Université Libre de Bruxelles, whose annual budget has been cut by 10 per cent, has started up a special unit to help seek outside finance and markets for the university's research.

The cutbacks will also lead to a shake-up among Belgian academics. Professors will retire at 65 instead of 70 as at present, newly employed graduate researchers will be paid less than they are now and promotion will come more slowly and less frequently. The remaining professors may have to work harder, with inter-university chairs being created to allow experts to share their knowledge more widely. Jasper Becker 